\title{
Permitting a Homeless Transition Village: Transactions between the Informal and the Formal
}

HOUSING

\section{Stephen Luoni}

\begin{abstract}
More than three million Americans experience homelessness annually. Emergency shelter capacity is limited while local governments are unable to provide even temporary housing. Informal housing involving interim self-help solutions are now popular adaptive actions for obtaining shelter, despite nonconformance with city codes. Unfortunately, most informal solutions have resulted in objectionable tent cities and squatter campgrounds where the local response has simply been to move the problem around. Our homeless transition village plan prototypes a shelter-first solution using a kit-of-parts that can be replicated in other communities. Village design reconciles key gaps between informal building practices and formal sector regulations, creating a permittable solution under most city codes. While informality is traditionally associated with the "topography" of unplanned hyper-growth in developing nation economies - and not with design disciplines or advanced economiesour project highlights informality as a mode for effecting new urban solutions within obdurate regulatory environments. Indeed, the informal has emerged as an important design epistemology in advanced market economies given the polarization of their economies and the need for distributive justice.
\end{abstract}

Keywords: codes, homeless, housing, informal, prototype, sleeping units

Informal space can also work toward an adjustment of people to the power structure of society. It becomes then a safety valve for the strengthening of the formal system. To the extent that individuals can create informal space to solve their problems they can return to the formal system, which remains unchallenged, to continue their journey. (Michel S. Laguerre) ${ }^{1}$ 
More than three million Americans, or close to one percent of the population, experience homelessness annually. ${ }^{2}$ Emergency shelter capacity is limited while local governments are unable to provide even temporary housing. States and cities have declared homelessness to be an emergency. Moreover, unsheltered homeless populations prefer the street over formal emergency shelters given the lack of privacy, safety, and autonomy plaguing most shelters. ${ }^{3}$ Typically, shelters limit occupancy to overnight dormitory-style stays, requiring residents to cart their belongings throughout the day - more than a physical obstacle to fulfilling daily needs. Indeed, as Tent City Urbanism author Andrew Heben observes: "The question of where one will sleep on a given night - consumes significant mental resources and limits the capacity to focus on other tasks." ${ }^{4}$ Nor do emergency shelters provide transitional assistance or wraparound social services, equally important as a shelter in helping residents to recover their independence.

\section{PROTOTYPING A SETTLEMENT PATTERN}

Transitioning out of homelessness is a stepwise process involving needs beyond obtaining shelter. Re-building independence within the context of trauma and depleted social relationships is a communal, holistic endeavor focused on achieving equilibrium in mental health. Lack of reliable assistance coupled with extreme affordable housing shortages exacerbates personal crises. It is not surprising then that interim self-help building solutions have become popular adaptive actions for securing shelter and mutual aid among the homeless, despite their nonconformance to city codes. Some informal settlements have grown to become model communities through smart self-organization (Fig. 1). Unfortunately, many other settlements have resulted in objectionable tent cities and squatter camps offensive to surrounding property owners where the local response has been to simply disband those communities and move the problem around. This recalls Friedrich Engels' now-famous observation in his 1872 pamphlet, The Housing Question, that the bourgeoisie's solution to the "housing problem" (worker housing) has been to displace it only to find it pop up elsewhere, and the cycle repeats. ${ }^{5}$ Engels' prescient observation about universal accessibility to housing still holds.

The University of Arkansas Community Design Center designed a homeless transition village for a local homeless service provider to replace a tent city in the woods near downtown Fayetteville, Arkansas (Fig. 2). Designed as a kit-of-parts to accommodate both professional and volunteer construction labor, the village prototypes an affordable shelter-first solution ${ }^{6}$ which can be replicated in other cities. Transition village planning begins with the intelligence embedded in the informal genre of tiny home villages, camps, and tent cities - all based on the productive relationship between individual sleeping units and communal facilities. However, municipal codes governing residential land use employ the autonomous dwelling unit as a 


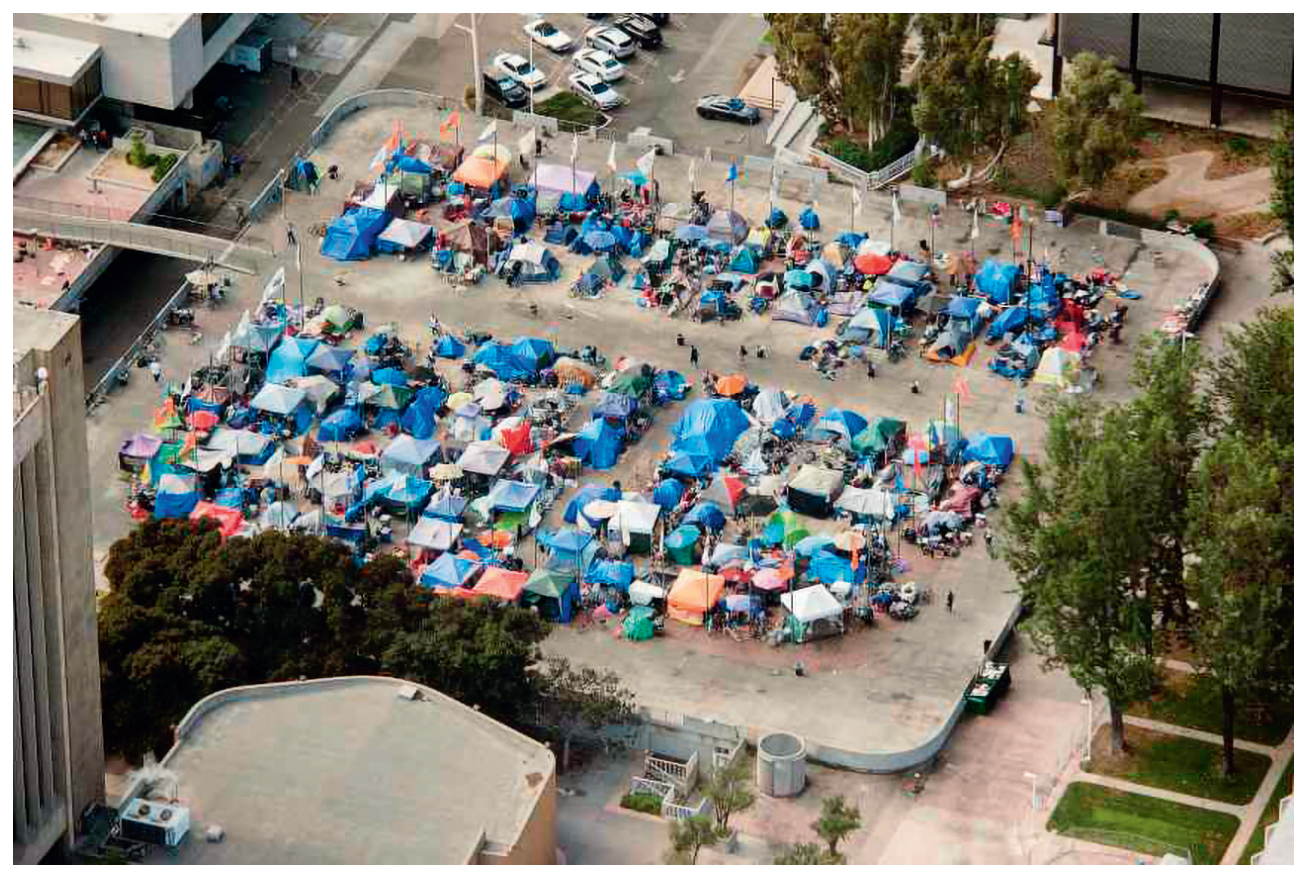

Figure 1. A well-organized tent city in Santa Ana, California.

minimum regulatory standard requiring plumbing, electrical, sanitation, and cooking services. Sleeping units may offer some or none of these services. Our housing settlement pattern was not permittable under the city's regulatory framework, which, like most cities, is based on the International Residential Code and the International Building Code among others. Without having to change zoning and building codes, our village design was granted a five-year conditional use permit from the City of Fayetteville to test its viability as a transitional community. The project reconciles key gaps between workable informal building practices and formal sector regulations

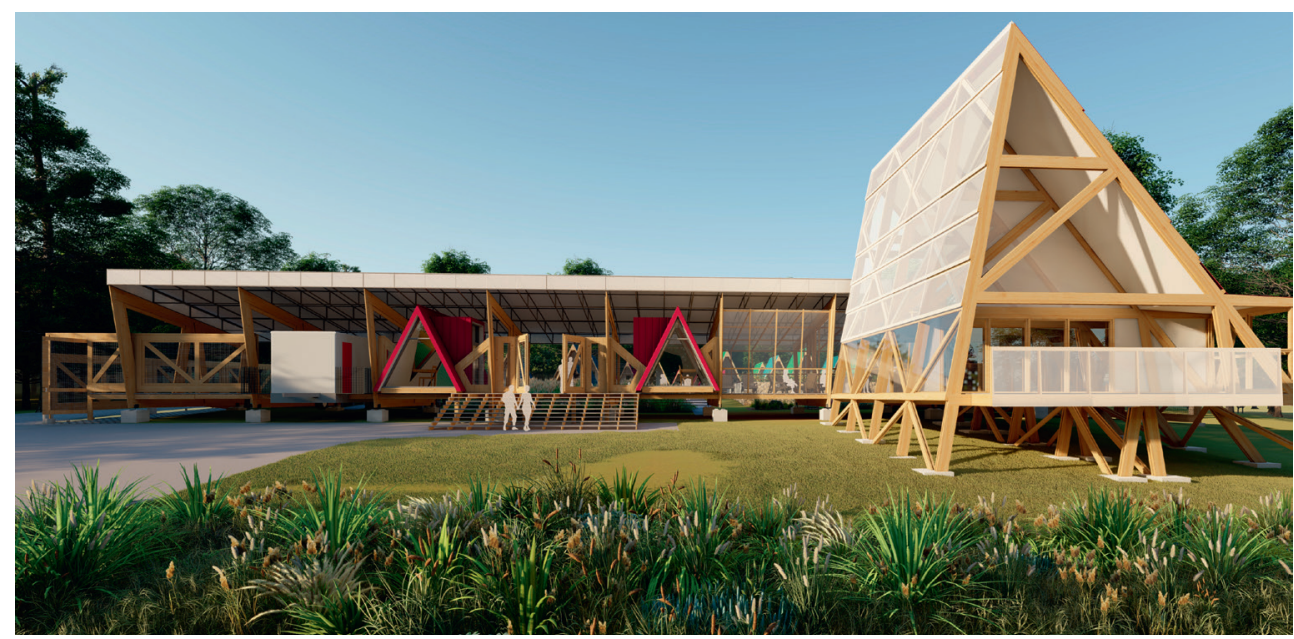

Figure 2. Community Porch, the public face of the New Beginnings Transition Homeless Community: Fayetteville, Arkansas. 
to secure a permittable and affordable solution, albeit with conditions. The long-term objective is the legalization of both the transition community as an interim land use and its more permanent offspring, the tiny house community. Currently, outside of the formal sector, micro-housing typologies are missing solutions in addressing the nation's affordable housing crisis.

Informal communities are instructive life-worlds, often exhibiting high levels of social capital and participatory structure that typically atrophy in formal systems. Yet, we customarily see informal and formal sectors as two distinct topographies, the former an anomaly produced by the poor waiting to become legitimate as it moves toward the sanctioned latter. Urban scholar Saskia Sassen turns this understanding on its head, arguing that informalization is not only embedded in our political-economic structure but is ultimately produced by that very structure. Informalization is more a development modality than simply a sub-sector practice of one economic class, which is why the standard criminalization of the informal is not effective policy. Indeed, informalization crosses all class lines as a shared survival strategy, particularly in advanced market economies that incline towards a monopolistic structure. Even in advanced economies, legitimate work sectors often house informal back-room components that support otherwise formal business models. Uber and Airbnb are cases in point of middle-to-upper class informalization. Reinforcing her point that informalization may not be an anomaly but rather structural to social and economic advancement, Sassen writes:

Informalization emerges as a set of flexibility-maximizing strategies employed by individuals, firms, consumers, and producers in a context of growing inequality in earnings and profit-making capabilities. Its expansion invites us to focus on the broader fact of a growing set of problems in the relationship between new economic trends and old regulatory frameworks. ${ }^{7}$

Behind many legitimate successes were informal beginnings. With these notions of the informal and the formal in mind, three planning principles guide the development of our homeless transition village's five-year lifecycle: formulation of a shelter-first solution, a transferable pattern language, and a prefabrication program for disassembly.

\section{Principle 1: Shelter-first Solution with Wraparound Social Services}

The transition village is a shelter-first solution offering individual sleeping units for six-month stays to build "housing readiness" among residents. The goal is to transition unsheltered populations to permanent housing. Twenty to thirty A-frame sleeping units or hard tents at $120 \mathrm{sq} . \mathrm{ft} .\left[11 \mathrm{~m}^{2}\right]$ equipped with services limited to mini-heating/cooling units and USB outlets provide the security and privacy missing in the daily routines of vulnerable populations (Fig. 3). Since half of local fire deaths result from homeless 
populations cooking, smoking, or providing heat in their tents, ${ }^{8}$ the sleeping unit will not be the sole source of services for individuals. Instead, cooking and sanitation facilities are provided in the community super-porch, discouraging residents from hibernating in their sleeping unit. While A-frame cabins have certain functionality challenges, their ease of construction by amateur contractors and volunteers, material efficiencies and affordability, portability, and familiar domestic iconicity fulfil multiple criteria.

Residents share communal facilities, including a kitchen, sanitation facilities, laundry, offices for counseling, and workspaces clustered under a community super-porch. Shared facilities are supported by a day kennel (many have dogs, inconvenient when searching for housing and jobs) and a community hall, which can be plugged into the super-porch in a later phase of development. Visiting social work professionals provide wraparound counseling services along with transitional assistance in securing housing and employment. Akin to the cooperative relationships ordinarily forged in informal settlements, the village's covenants with residents requires self-governance, accountability, and service to the village as reciprocity for boarding. The village's size is scaled to the workload manageable by one caseworker and the optimum resident count for maintaining quick communications while having economies of scale.

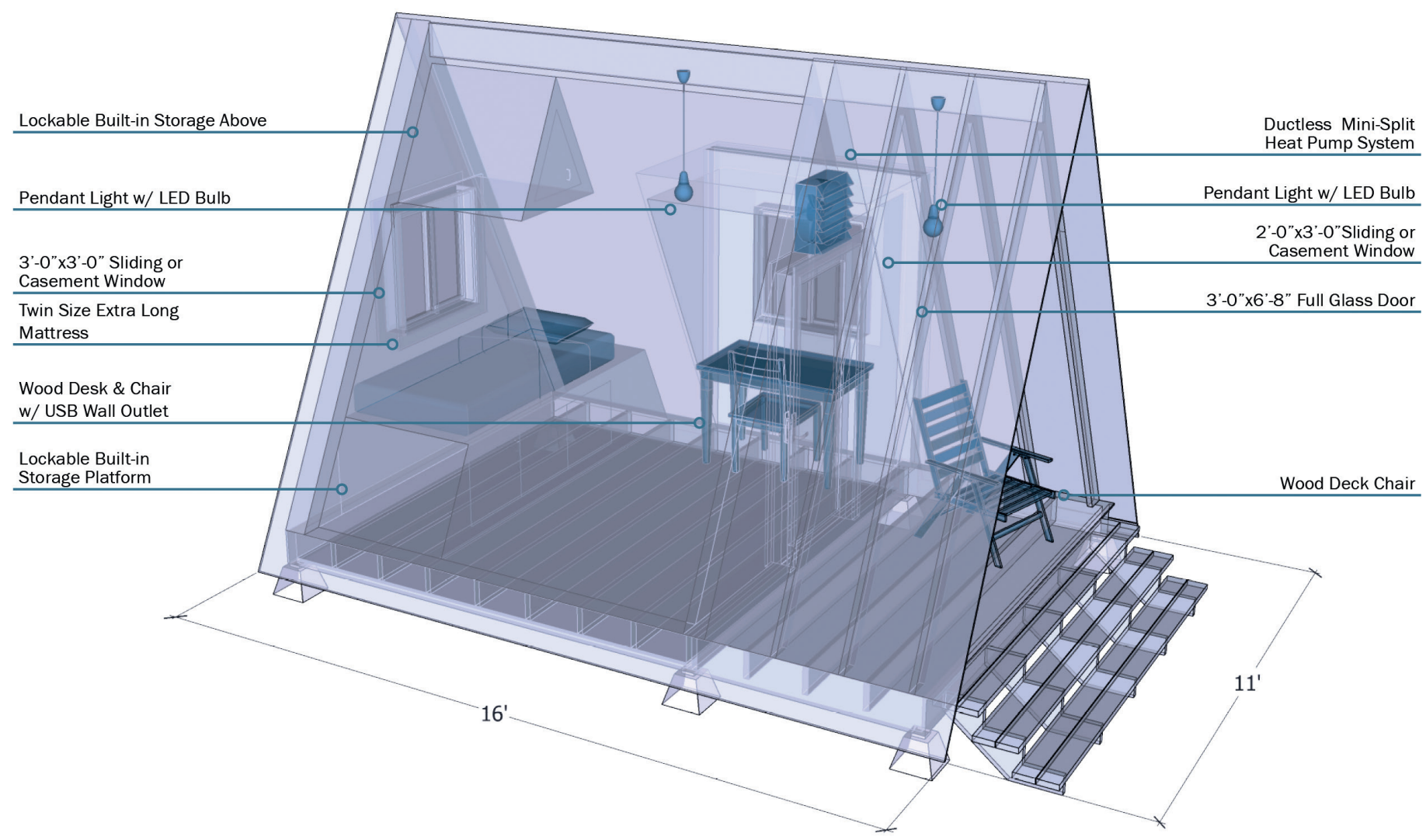

Figure 3. A-frame sleeping unit at $120 \mathrm{sq}$. $\mathrm{ft}$. [11 $\left.\mathrm{m}^{2}\right]$ with mini-heating/cooling units and electrical service provide the security and privacy missing in the daily routines of the homeless. 
Clearly, there are demographic trends as to who becomes homeless. In our partnership with Serve Northwest Arkansas, an established local homeless services provider, we learned that the average length of homelessness is thirteen months and in Northwest Arkansas, 30\% of homeless adults are chronically homeless - homeless for one year or more, homeless at least four times in the last three years, and presenting a medical condition. In Northwest Arkansas, a high-growth region with low unemployment, the homeless population is predominantly male $(70 \%)$, single $(68 \%)$, white (85\%), and the median age is forty-two years. A chronic condition is reported at least once by $70 \%$ - mental health (45\%), substance abuse (40\%), physical disability (25\%), and domestic violence (15\%). Approximately $30 \%$ are veterans according to Kevin Fitzpatrick, a professor of sociology with national expertise in homelessness and a board member at Serve Northwest Arkansas, ${ }^{9}$ which will build and manage the transition village, called New Beginnings.

The intersectionality of poor health, unemployment, and lack of resiliency associated with isolation is compromising people's ability to secure stable housing. Fitzpatrick, who has studied the local homeless community for well over a decade outlines the chronology of needs beginning with shelter/ housing first - a reversal of the mainstream "continuum of care" approach that mandates behavioral changes as prerequisites to acquiring permanent housing. ${ }^{10}$ Fitzpatrick writes:

Unquestionably a number of important themes have emerged. One, significant health care needs are missing and attention to these needs must be an important part of any service provision particularly mental health care needs related to monitoring of pharmaceuticals and counseling. Both of these health concerns are important to maintaining a stable and secure environment for clients with an effort to secure and maintain stable housing security. Two, many unsheltered clients lack adequate bridge housing (housing that can support their transition from unsheltered living to more permanent housing). As such, we are the only service provider that is actively engaged in developing bridge housing that can be vital to providing stability and security that is necessary to begin the arduous work of finding permanent, secure, stable housing. Regardless of the issues that persons experience, research clearly shows that some degree of housing stability is important to begin work on combatting a host of other problems that keep people in the cycle of poverty and homelessness (shelter/housing first model). Finally, job security is certainly something that most desire and without some stability in housing, working on securing a job that can provide support for housing security is impossible. Individuals cannot get to job interviews, work on their job applications, make phone calls and write emails without some housing/shelter security. ${ }^{11}$ 


\section{Principle 2: Codify a Pattern Language for Universal Application}

The project upgrades, ${ }^{12}$ rather than criminalizes, informal settlement configurations, moving aspects of housing closer to compliance. The village codifies a settlement pattern language that transfers information and methods for addressing common regulatory obstacles. Three fundamental components constitute a transitional village settlement: single-occupancy sleeping units, a secure perimeter, and a community porch (Fig. 4). Weather-proofed and insulated sleeping units (not to be confused with dwelling units that necessarily provide sanitation and cooking services) replace the fabric tents of the former tent city. Each unit is assigned a mailing address and provides a protected place to store personal belongings and pets. Freedom of movement allows residents to pursue employment, housing, and support opportunities. Unit subgrouping around patios, a scale in between that of the individual unit and the total project, assists in generating a sense of belonging and effective village self-governance seen in informal patterns.

A secure perimeter provides safe habitat among homeless populations who routinely experience violence, personal transgressions, and countless indignities in both formal shelters and pop-up tent cities. Tent cities can

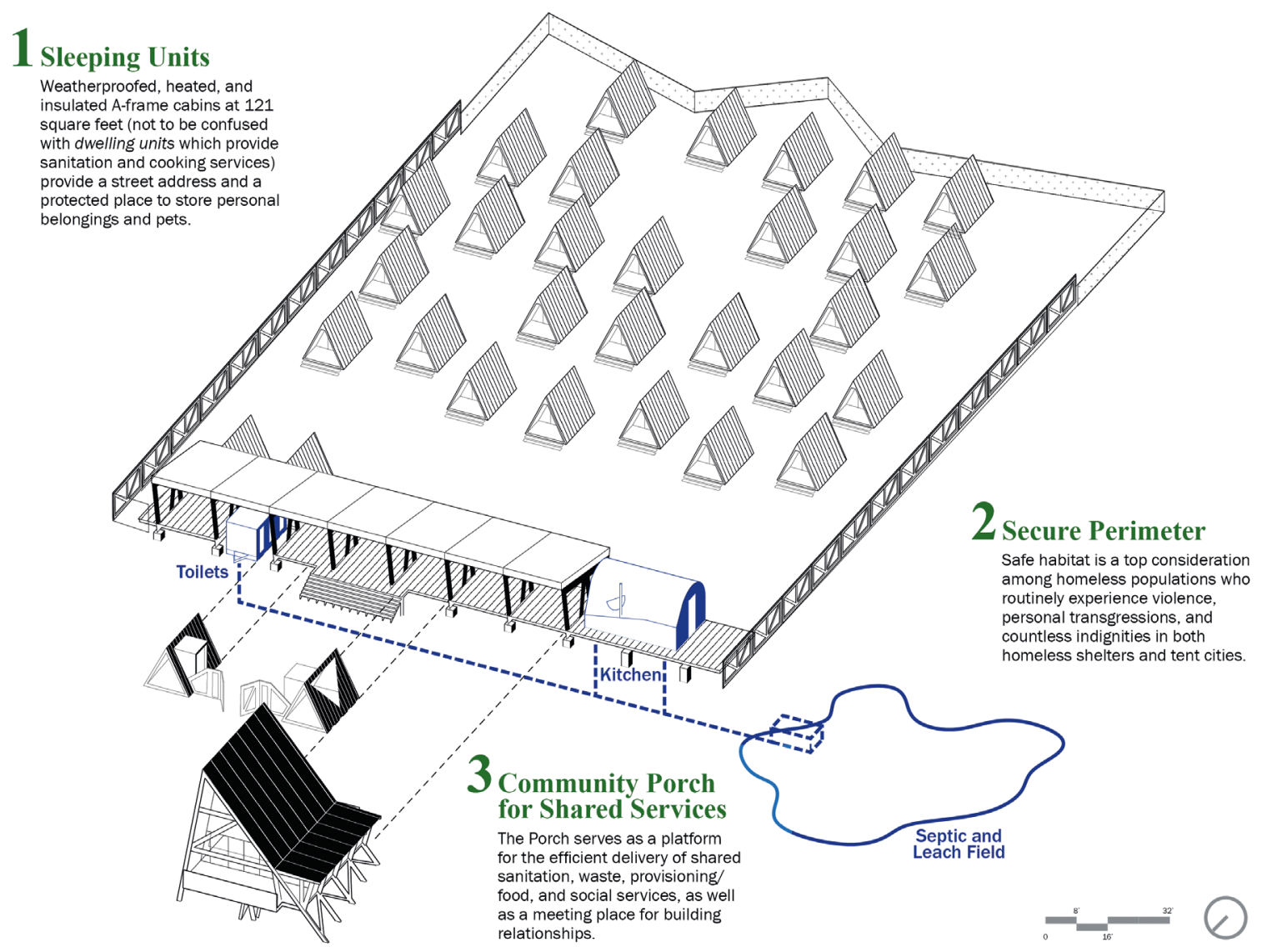

Figure 4. The three components of a transition village prototype. 


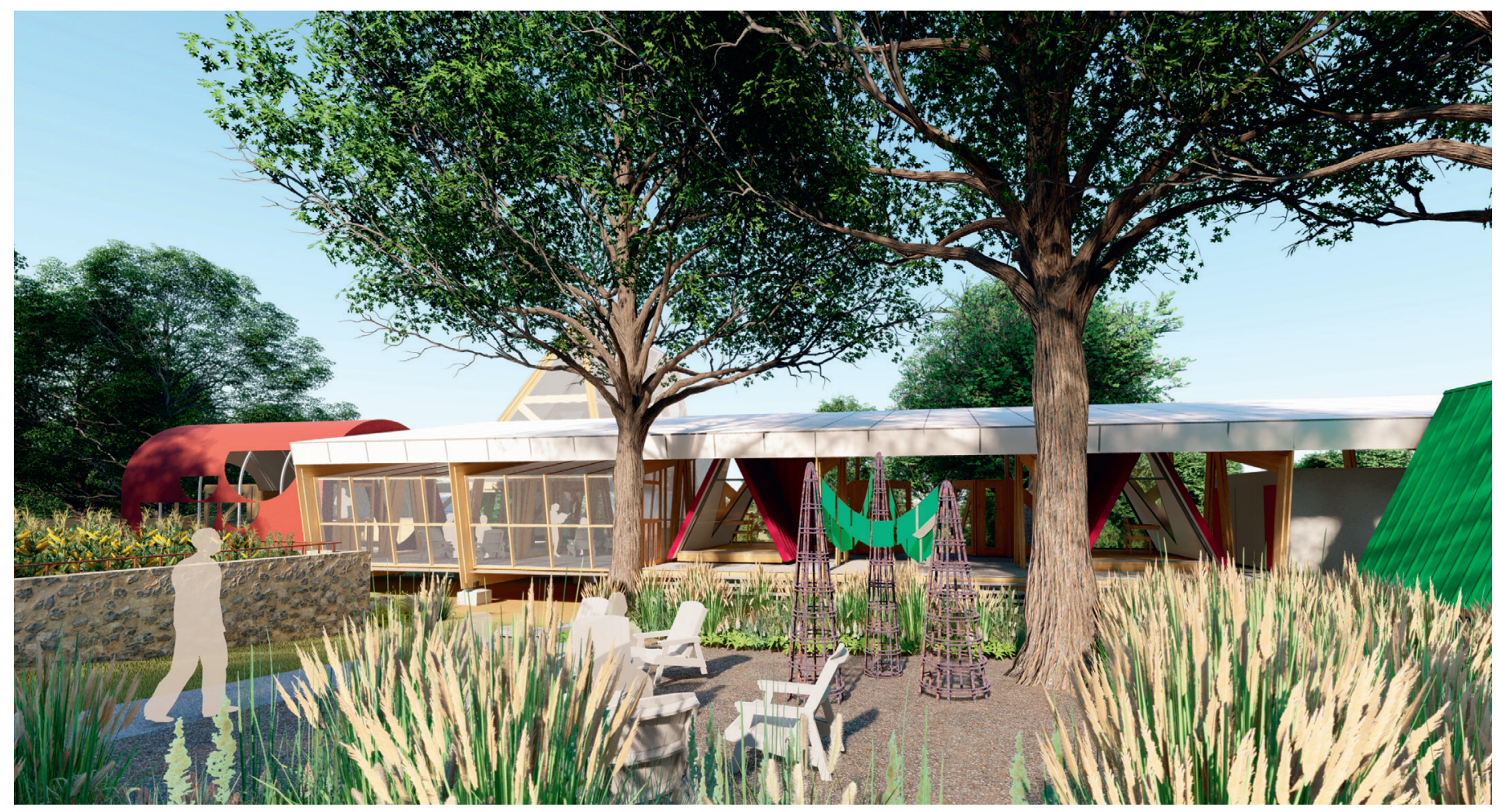

Figure 5. Looking from the common, the $150 \mathrm{ft}$. [46 m] long community porch serves as a platform for the efficient delivery of shared sanitation, waste, provisioning/food, and social services.

be volatile and unpredictable places, simultaneously exhibiting the worst dysfunctions and the highest levels of cooperation within short spans of time. Effective self-governance and village management stemming from a secure environment are key to winning acceptance from neighbors and overcoming the NIMBYism (NIMBY: Not in My Backyard) that discourages municipalities from issuing conditional or discretionary use permits.

A $150 \mathrm{ft}$. [46 m] long community super-porch fronting the street serves as a platform for the efficient delivery of shared sanitation, waste, provisioning/ food, and social services, which closes the gaps on health and life safety standards plaguing informal settlements (Fig. 5). The village layout daylights this once invisible community, creating a dignified public interface while providing emergency vehicle access required by fire code. We never lose sight of the "deep community" characterizing the best informal settlements and that is transmitted into our village planning (Fig. 6). Patterns transmit information, ways of knowing or epistemologies, and often nestle legacy solutions from multiple traditions. Amidst a national housing crisis, the emergence of tent cities and other informal settlements indicates the need for replicable shelter/housing solutions near downtowns where homeless populations benefit from close access to jobs, transportation, and services. Yet, many settlements are forced to locate in unincorporated areas to escape municipal regulation, further complicating the transition to securing employment and permanent housing. 


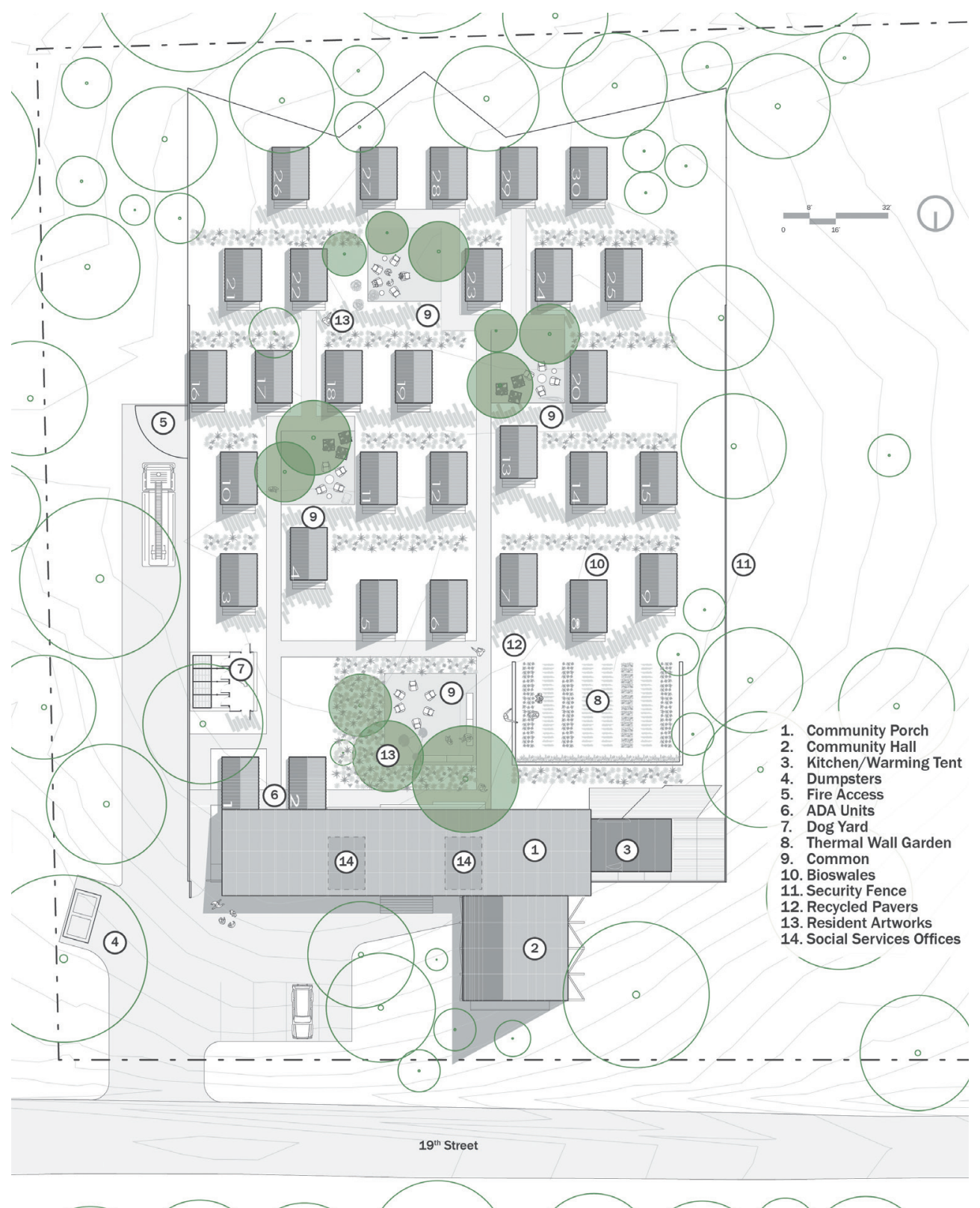

Figure 6. Three planning principles: formulation of a shelter-first solution, a transferable pattern language, and a prefabrication program for disassembly.

\section{Principle 3: Prefabrication for Disassembly and Reuse, not Demolition}

Given the village's five-year lifespan, all construction is componentized and designed for disassembly and reuse, whether as whole building units, structural systems, or wall and floor panels (Fig. 7). Except for installation of in-ground utilities and foundation work, the village is designed as if it were a carnival: here today and gone tomorrow with minimal site disruption and quick set up elsewhere. Village design minimizes environmental disruption to the site and eliminates the concept of waste through a flexible kit-of-parts made for disassembly and adaptive reuse or "upcycled" for an even higher 


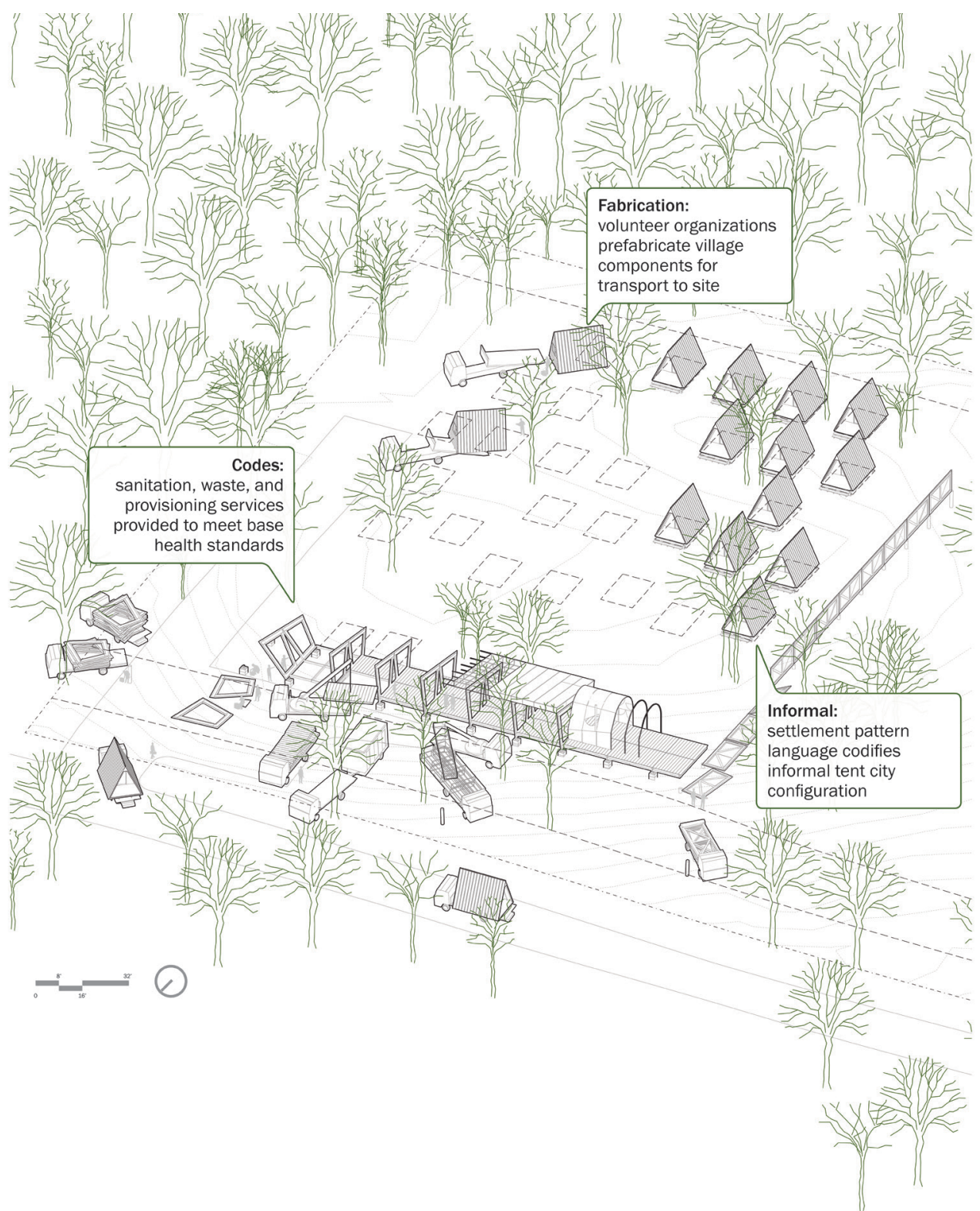

Figure 7. Towards a circular economy: prefabrication for disassembly and reuse, not demolition.

level of productivity elsewhere. Upcycling stimulates a circular material economy, extending the resourcefulness already underwriting many informal practices. Indeed, informalization often pioneers an ecological vision out of necessity while pushing the formal to acknowledge new socio-economic challenges. Likewise, design culture pushes backsolving for life safety requirements rightly demanded in formal regulation.

Building components are prefabricated off-site and flat-packed for transport and assembly to minimize on-site construction. On-site construction is limited to excavation for water supply, waste disposal, foundations, electrical conduit, and storm-water management. Efficient A-frame 
sleeping units are designed to accommodate remote construction by volunteer nonprofit organizations. Unit dimensions are defined by transport requirements and moved as whole buildings (Fig. 8 ). The community superporch is a more complex plug-and-play armature accommodating services and hosting integral subassemblies, including a kitchen and a warming tent made of vinyl, a toilet/shower trailer, accessible sleeping units, modified A-frame offices, screened social room, and future plug-ins as needed. The porch's main section consists of wood-sandwich space trusses topped by a metal awning frame supporting a stretched fabric canopy. Porch floor modules made from structural insulated panels (SIPs) are weatherized, housing water supply and electrical services (we are in a temperate climate with freeze-thaw cycles). For general safety, trussed fence panels secure porch and village edges (Figs. 9, 10, 11).

A community hall to be plugged in at a later phase is assembled by stacking and clipping three sets of prefabricated wood trusses in an asymmetrical A-frame structure (Figs. 12, 13). Design for disassembly requires reversible "dry" material connections (e.g., bolts v. welds) that are not concealed.

Disassemblers must be able to readily access structural connections. ${ }^{13}$

Once the problem of unsheltered homelessness abates, village components can be dismantled and reconfigured elsewhere or sold individually given their use value. For example, the community porch could become a social anchor in a tiny home community or an enclosed play area for an elementary school. A-frame sleeping units can become park cabins, children's playhouses, or field offices. Trussed fence panels are handsome and especially reusable in formal settings. The next section addresses the common gaps between formal regulations and the village pattern language, outlining general points of negotiation with city authorities. Keep in mind that each of the fifty states has their own mix of laws governing the three sets of codes used by cities - zoning, building, and housing codes which both enable and disable cities from enacting desired local reforms.
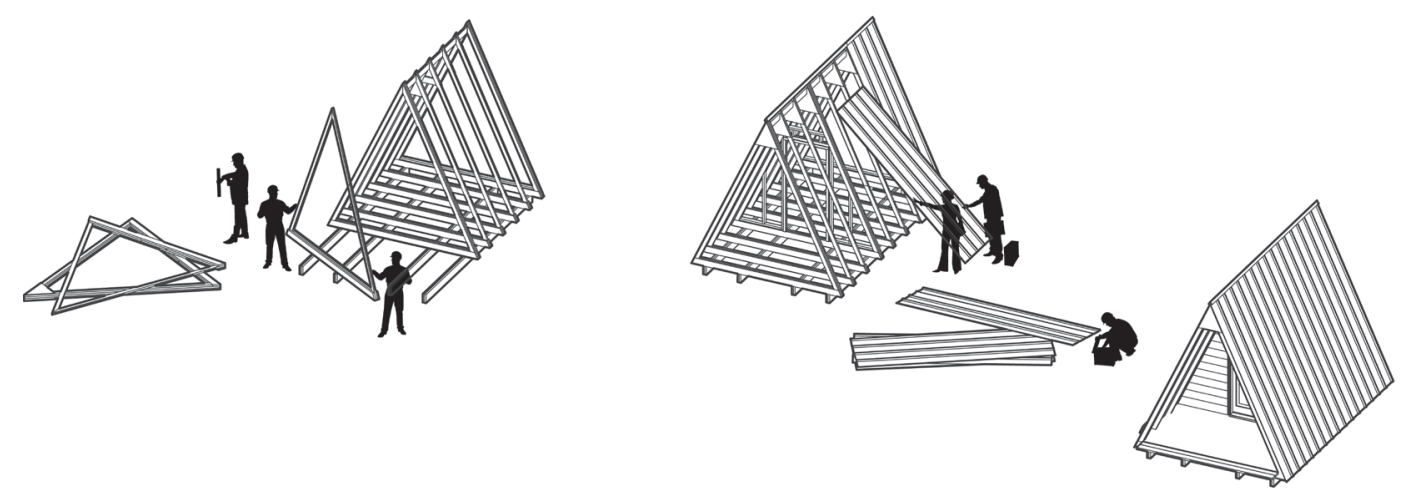

Figure 8. Sleeping units are prefabricated by volunteer organizations. Unit dimensions are defined by transport requirements and moved as whole buildings. 


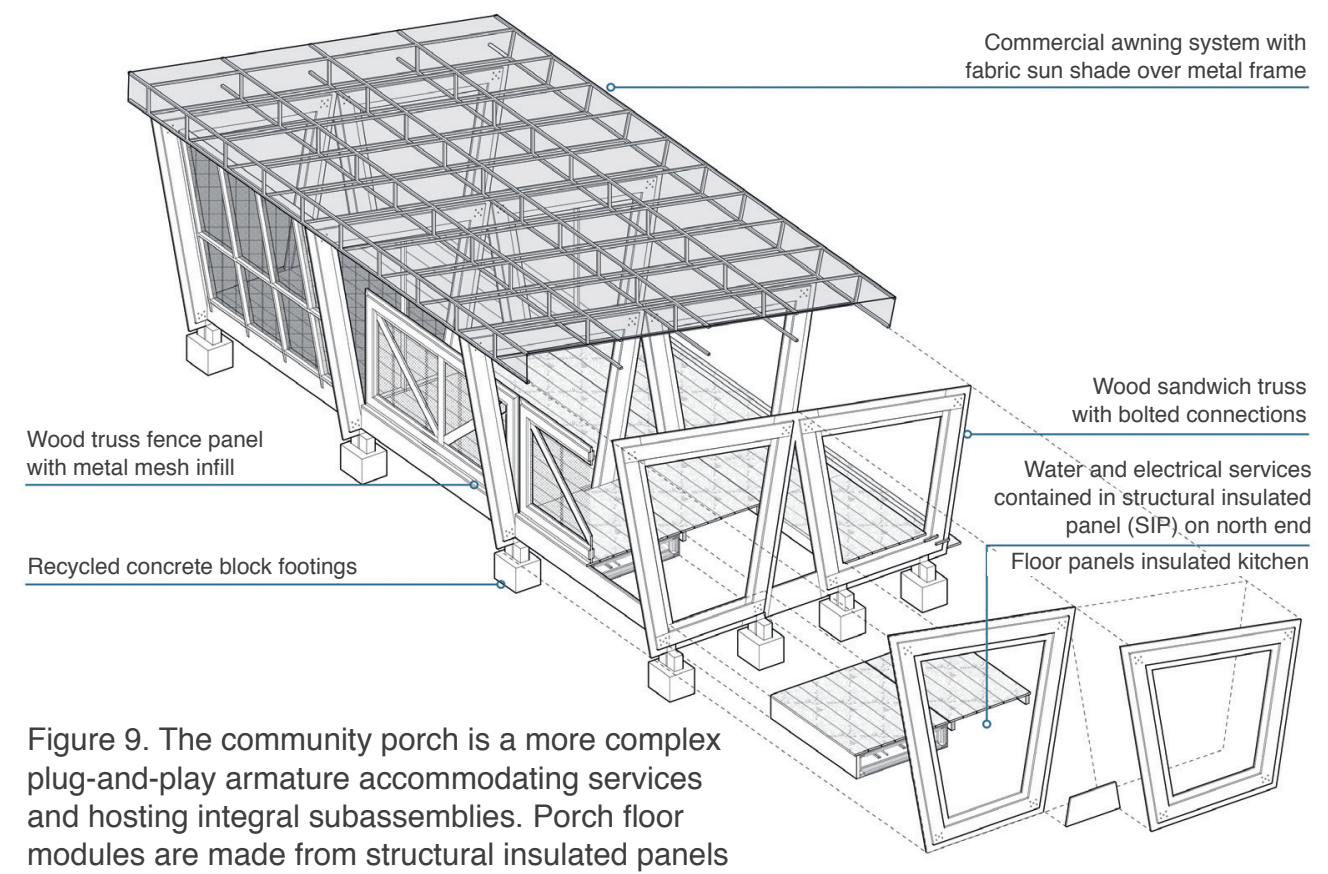

(n) panels

(SIPs) housing water and electrical services.

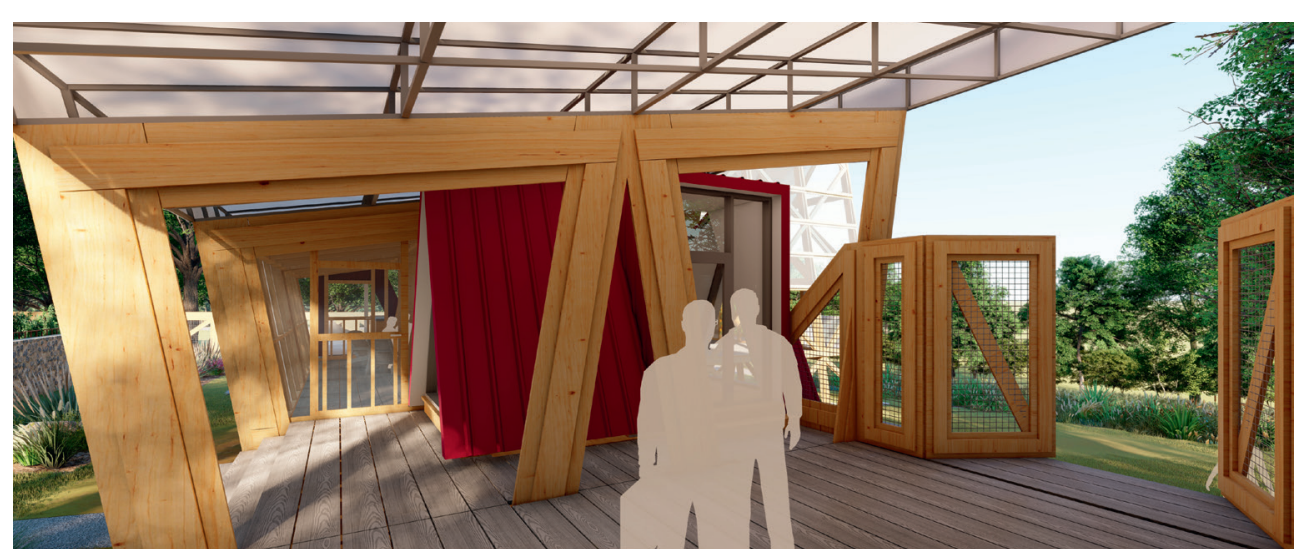

Figure 10. The porch's main section consists of wood-sandwich space trusses topped by a metal awning frame supporting a stretched fabric canopy.

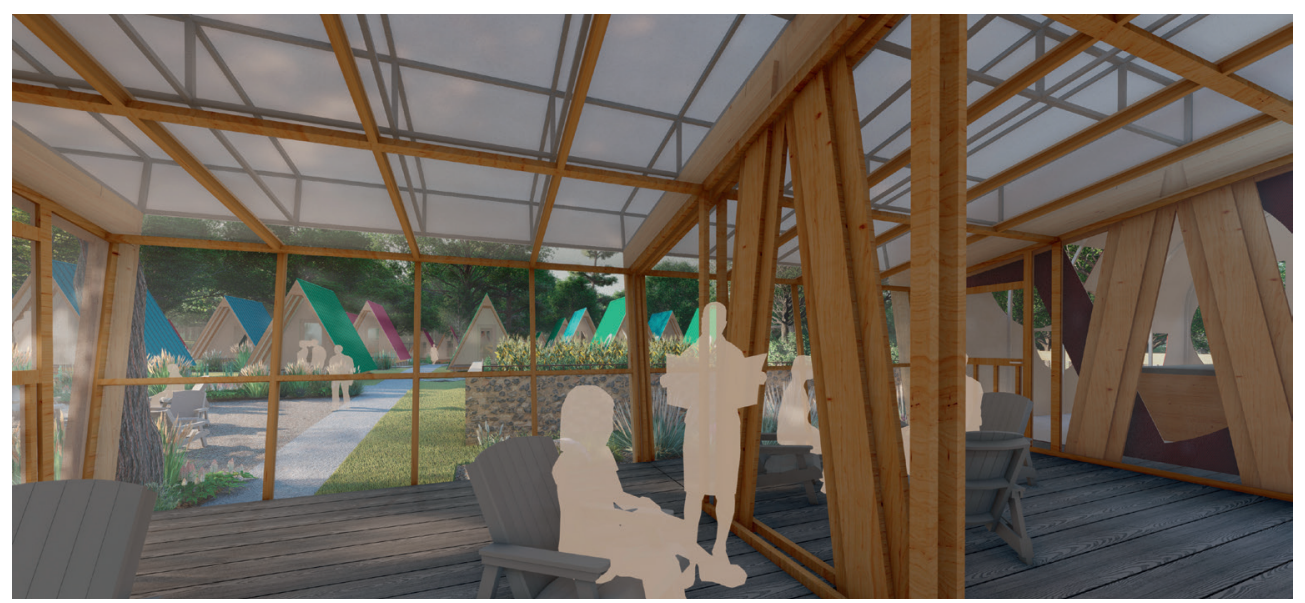

Figure 11. Screened room provides social and multi-purpose space for residents. 

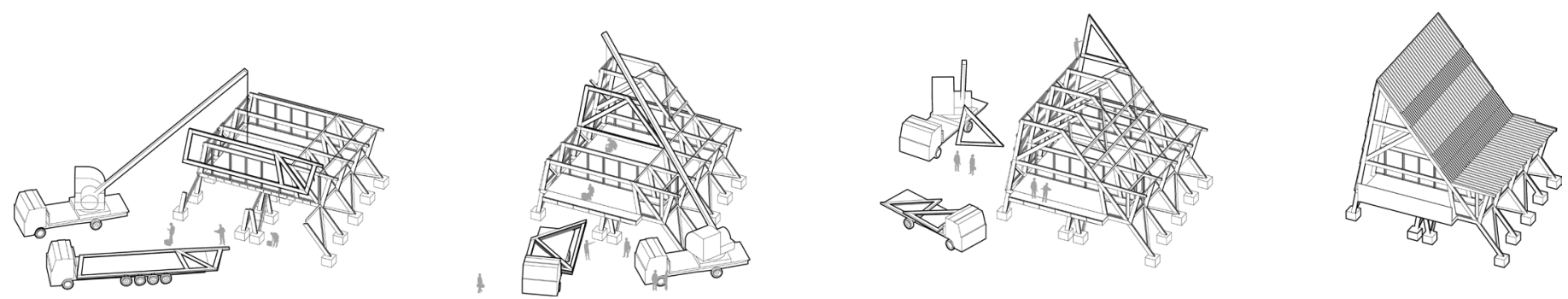

Figure 12. A community hall is assembled by stacking and clipping three sets of prefabricated wood trusses in an asymmetrical A-frame structure.

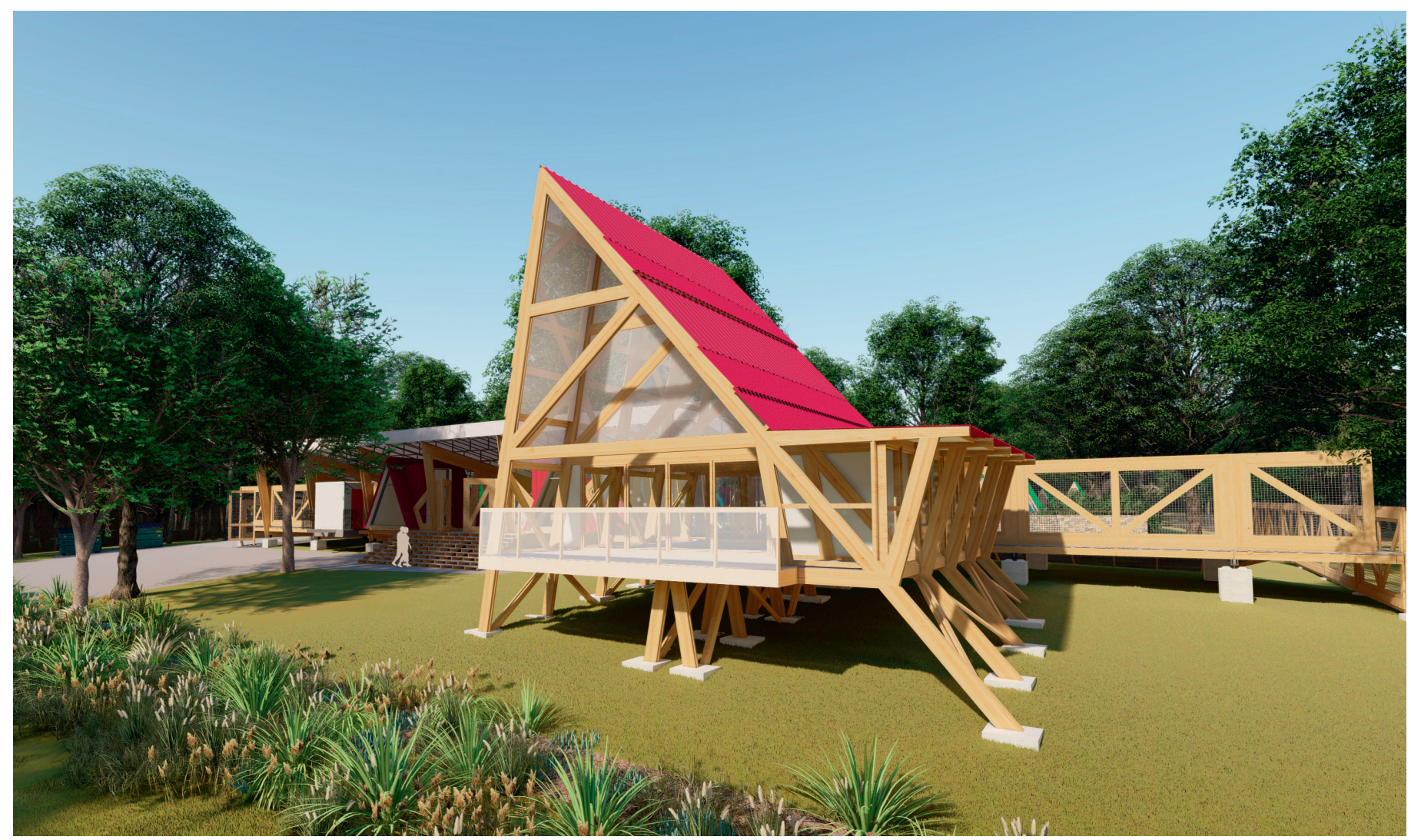

Figure 13. The community hall's asymmetrical A-frame is responsive to different edge conditions and solar orientations.

\section{RECONCILING FORMAL ZONING CODES AND TRANSITION VILLAGES}

\section{Is Campground Classification Helpful?}

If a structure is built on a foundation, then building codes apply. If it is on a trailer and axle, then it is a "move-on" structure inspected only for connection to utilities - water, sewer, and electricity. Many localities do not allow utility hookups except in designated land uses, including a homeowner's property. Trailers must meet the criteria of the 
National Highway Traffic and Safety Administration. Vehicles in designated campgrounds are commonly limited to ninety-day stays for recreational purposes, while mobile homes are subject to conditional use permits in cities and are usually excluded from residential areas. Most cities have anti-camping ordinances, including vehicle camping. While it seems intuitive to classify the transition village as a campground, existing land-use classifications for campgrounds, tiny houses, and RV Parks limit stays and do not work for homeless transition villages. Short-term options include seeking conditional use approvals, consent decrees, or even negotiated planned unit development designation to permit transitional villages. Long-term code reform entails seeking new state-level zoning classification for "transitional villages" (not to be confused with professionally-staffed transitional housing in the formal sector) permitting temporary housing and alleviating the need for drastic overhauls to current zoning and building codes. ${ }^{14}$ Currently, Oregon is the only US state that permits transitional housing, its statutes enabling localities to develop contextsensitive solutions within urban boundaries without fundamental changes to existing zoning, building, or housing codes. ${ }^{15}$

\section{Obligation of Property Owners to Improve Streets}

Municipal codes require property owners improving their properties to concurrently improve right-of-way on which their properties front. Owners are obligated to bring right-of-ways into compliance with current codes usually involving installation of sidewalks with curb and gutter, setbacks, and street trees/tree lawns beyond the necessary connections to water, sewer, communication, and electrical utilities. However, conditional use permits like those granted to our project should trigger waivers from making permanent upgrades to street infrastructure if they do not compromise public health and safety.

\section{Required Environmental Review}

Development beyond one-acre improvements triggers an environmental review in some cities governing stormwater management, tree canopy (required 20\% coverage in Fayetteville) and hillside preservation, and compliance with the Americans with Disabilities Act (ADA) for accessibility. To avoid hard engineering costs for stormwater runoff management, design the site employing Low Impact Development stormwater runoff management techniques or "soft engineering." ${ }^{16}$ Minimize impervious surfaces to optimize runoff infiltration. Ecologically-based stormwater runoff treatment strategies substitute bio-swales and infiltration basins for costly hard engineered pipes and detention ponds (a street-facing detention pond may not be permitted by the city). Preserve trees as they create the discrete environment homeless populations seek while providing shade and water management services. While it is not clear if units are required to comply with ADA requirements, for goodwill purposes design ten percent of sleeping units to be compliant with accessibility standards. The complexity and conditional 
approval status of transitional villages will likely prompt an additional largescale development review by the city, as it has in our case.

\section{Importance of a Host Organization in Securing Approval Under Formal Regulations}

The transition village's conditional use permit is based on having a sponsoring organization - in this case, Serve Northwest Arkansas responsible for construction, compliance, and village operations. Some cities may even require the organization to own the land. ${ }^{17}$ Transition villages can also be sponsored by a host local government that ensures compliance in construction and operations. Note that the federal government's 2000 Religious Land Use and Institutionalized Persons Act grants churches automatic right to sponsor transitional housing on their properties pursuant to their ministries, overriding local zoning authority. ${ }^{18}$

\section{Fire Truck Access and Fire Separation Requirements}

The International Fire Code governing access to property requires all structures to be within $150 \mathrm{ft}$. [46 m] of a $20-\mathrm{ft}$. wide [6 m] drive for fire truck access. The maximum length of a fire lane from the street is $150 \mathrm{ft}$. before requiring a $100-\mathrm{ft}$. wide [30 $\mathrm{m}$ ] turnaround - equal to one-fifth the area of our village's enclosed grounds. Building address numbers identifying each unit are to be displayed on their exteriors to guide emergency responders. A 10-ft. [3 m] distance between structures is required to achieve a two-hour fire separation. You will likely not supersede fire access codes, so scale the plan geometry accordingly to avoid undue expenditures on fire access infrastructure, which requires a paved or unpaved lane with a structural substrate to support an $80,000-\mathrm{lb}$. [36.287 kg] truck.

\section{Zoning and Land Area Encumbrance}

Zoning needs to be at least R24 - max. 24 units/acre [60/ha] - to permit the village's desired unit count of twenty, including eventual expansion to thirty units. Sleeping unit layout is land consumptive due to fire separation requirements between units and required setbacks from the right-of-way.

\section{RECONCILING FORMAL BUILDING AND HOUSING CODES AND TRANSITION VILLAGES}

\section{Sanitation Is a Top Concern - No Porta-Potties}

Existing municipal codes require connection to water supply and sewer while state law disallows composting toilets and greywater recycling systems. Codes disallow portable toilets that cannot be connected to a sewer or septic system. Since sanitation is the primary concern in maintaining a conditional use permit, ensure that bathrooms are always clean, in top working order, 
and pose no health risks. This favors the option of city sewer over septic systems since the latter is more challenging to maintain.

\section{Dwelling Unit vs. Sleeping Unit Classification}

The International Building Code requires that dwelling units have toilets, bathtub or shower, kitchen with a sink, hot and cold water connections, and a sewer connection. Transition villages are congregate living facilities where sleeping units are supported by shared facilities. Fayetteville classified our A-frame structures as sleeping units given their limited utility connections (except for electricity for heating and light). Plumbing, waste and sanitation utilities are congregated in the community super-porch. Note that sleeping units are governed by the International Building Code instead of the International Residential Code, requiring a minimum room size of $70 \mathrm{sq}$. ft. [6.5 $\left.\mathrm{m}^{2}\right]$ with a minimum ceiling height of $7 \mathrm{ft}$. [2 $\left.\mathrm{m}\right]$. The latter prohibits lofted sleeping spaces. While some localities require a minimum square footage of $200 \mathrm{ft}$. [61 m] for habitable living space in dwelling units, most require substantially larger minimum areas for housing units. ${ }^{19}$

\section{Sleeping Unit Classification Requires Sprinklers}

The 120-sq. ft. [11 $\mathrm{m}^{2}$ ] sleeping units - along with motels, dormitories, and other bedrooms for hire - are classified as commercial use and thus require an automatic sprinkler system in each unit, entailing costly plumbing insulated from winter weather. Automatic smoke detectors and an alarm system networked to the local fire department are also required. The cost of this premium fire suppression system in each sleeping unit is financially unfeasible. Before negotiating an alternative plan, keep in mind that fire marshals rightfully value life over property in making their decisions. Since small sleeping units with minimal services reduce fire risks, we were able to substitute a program of operational guidelines for sprinklers and tie-in alarms. The guidelines include a 24/7 fire-watch to be crewed by residents accompanied by a battery-operated Smoke/CO alarm in each unit and one fire extinguisher per two structures mounted on the exterior. Smoking, cooking, and extension cords are prohibited in sleeping units. ${ }^{19}$

\section{Shared Kitchens Are Commercial Kitchens}

Health department codes deem shared-use kitchens to be commercial kitchens, while some states prohibit common kitchens altogether. ${ }^{20}$ Commercial kitchens require three sinks, a grease trap, and a commercialgrade ventilation hood. Since you will likely not supersede health codes, expect to comply fully. A food truck may provide a less expensive option to a fully equipped kitchen, but do not undervalue the kitchen and shared dining as a central communal component in achieving the goals of the transition village. 


\section{Open-Wall Building Inspections}

Many local codes require on-site inspection of building wall sections before installation of finished surfaces, precluding total prefabrication of the unit. The city's energy code requires an R20-rated envelope, a primary point of assessment by inspectors. One option then is to conduct building site inspections at local sites of prefabrication before wall panels are sealed.

While this list is certainly not exhaustive nor capable of covering the wide range of local nuances, it does address the primary obstacles impeding approval and/or impacting design considerations at the outset of planning. The next section concludes with some observations about the informal as a way of thinking, a cognitive model for approaching the urban design project through the housing question.

\section{INFORMALITY AS A "MODE" OF URBANIZATION}

Informalization is traditionally associated with the "topography" of unplanned hyper-growth in developing nation economies, differentiated from advanced market economies and the design disciplines that shape the latter's built environments. As stated earlier, rather than see the informal as simply a physical environment, our project highlights informality as a mode of reform, an important distinction articulated by Ananya Roy in her examination of informality. ${ }^{21}$ Mode foregrounds the role of agency in reshaping urbanization within advanced regulatory environments, and such agency is not necessarily limited to low-income actors. Informality transcends class and is "demand" simply stepping in to meet the needs unfulfilled by regulated and limited supply - recalling Sassen's notion that informality is produced by the state itself (a point reinforced by Roy). Familiar examples of informality include neighborhood food trucks, childcare, shadow banking through check-cashing and moneylending services, farm-to-table food supply (community-supported agriculture or CSAs popular among middle-class households), and an affluent peer-to-peer economy led by Uber, Lyft, Airbnb, Getaround, Ebay, Zaarly, and TaskRabbit, the last being a freelance labor broker. In the case of our homeless transition village, the informal is an interim solution to meet emergency demand for shelter and community support that was once met through a flexible supply of affordable downtown housing in our nation's cities. Downtown micro-housing, once a staple of affordable housing, especially that servicing extremely low-income individuals, has been systematically eliminated over the past sixty years through urban policy.

The rise of transitional villages parallels the emergence of more communal real estate products in the form of tiny house villages, microhousing apartments, and co-housing economies not yet susceptible to financialization. This includes revival of outlawed single room occupancy hotels (SROs) where the bed, and not the house, was the basic unit of 
dwelling. ${ }^{22}$ Downtowns were once extensive landscapes of residential hotels and rooming houses providing a range of room and board services for the poor and wealthy alike. Since the demise of the versatile twentieth-century residential hotel as a legal housing option in the 1960s, policy, as Heben reminds us, "Has largely held the development of low-income housing to middle-class standards." ${ }^{23}$ Consequently, affordable housing cannot be developed without subsidies. Structural long-term housing shortages coupled with declining purchasing power will compel even the once-middle-class toward new cooperative structures of living again, urbanizations unfamiliar to the last three generations of Americans. A bourgeoning alternative housing economy beyond that for the homeless - seen in the rise of outlawed accessory dwelling units, SROs, pocket neighborhoods, cohousing, as well as in the ever more common practice of multiple families sharing a singlefamily home - is signaling the arrival of new forms of urbanization instigated by the informal.

North American cities are scrambling to re-entitle villainized housing forms compelled by the informal sector's reframing of supply and demand, most commonly seen in the widespread re-legalization of accessory dwelling units in urban neighborhoods. Perhaps any local design effort like our transition village can at least foreground legitimate claims within the informal, countering its criminalization by the formal sector. But we also hold out for changing rather obdurate regulatory frameworks to embrace workable interim solutions. The bigger picture identifies what architect Valeria Frederighi views as informality's larger power to interject "negotiable value in constantly reframing the rules of the game." 24 In her book The Informal Stance (2018), Frederighi poses a set of questions to design culture highlighting greater possibilities for designers' meaningful participation when the informal is understood as a mode rather than simply a picturesque sector to be upgraded. Cautioning against the unwitting "aestheticization of poverty" in nudging the political economy forward, the big question for her is not "how to combine formal and informal in a way that retains the advantages of both while resolving [or not] their failings?" Rather, it is: "How is it possible to recognize the powers at play in the making of cities? How does any kind of design work enter and carry any weight in a landscape of networks and flows? How does an individual or a firm take rides within a system of covert political and market-driven mechanisms?" ${ }^{25}$

Thus, the informal emerges as an important design epistemology in advanced market economies given the polarization of their impacts and the need for distributive justice, especially among disadvantaged groups. The formal sector routinely undervalues the benefits and transformative capacities in the informal, particularly in the latter's adjustment to new ways of knowing, or epistemologies. The role of design and planning, then, is to negotiate possibilities from spontaneous social and organizational action in the informal with regulatory frameworks and work through rather than against formal systems of authority. In discussing the dilemma of planning and policy 
orientations on this account, I return to Ananya Roy who invokes the line of feminist poet Audre Lorde: "The master's tools will never dismantle the master's house." ${ }^{26}$ Our transition village captures the three pressing renegotiables for design culture in confronting the planning apparatus as outlined by Roy: "Moving from land use to distributive justice, rethinking the object of development, and replacing best practice models with realist critique," all repositioning informality as "an important epistemology for planning." ${ }^{27}$ One way to empower the informal is to codify patterns and prototype solutions for distributed application, which is precisely how great small towns all over the U.S. were built pre-1930s. Many American cities were built from pattern books without professional designers, though designers and architects as the embodiment of the formal developed those very patterns that were replicated. Interestingly then, the ordinary American city up to the early twentieth century was a product of informality, benefitting from the transmission of formal expertise to informal local actors who developed and built cities of similarly high quality (Fig. 14).

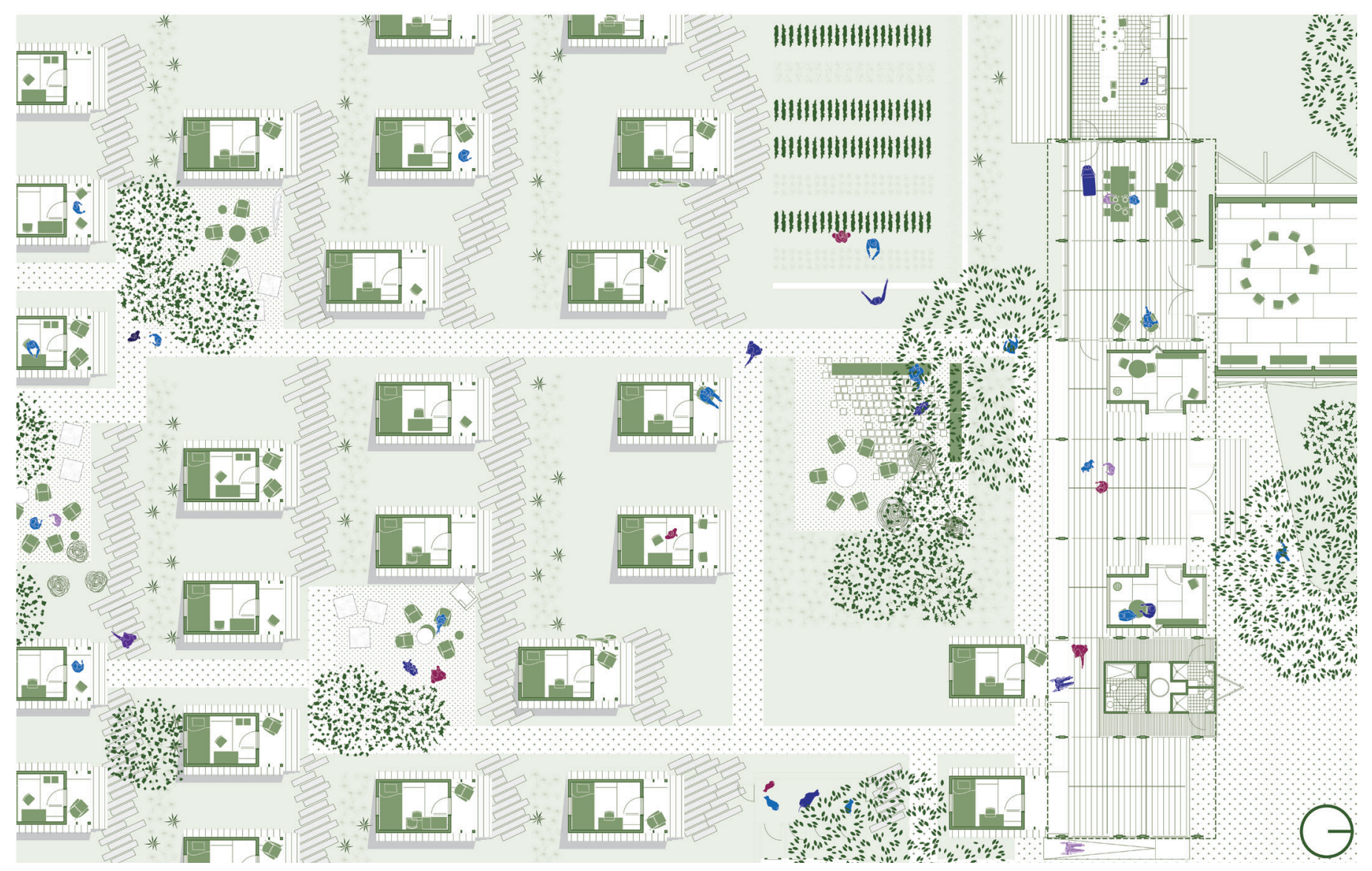

Figure 14. New cooperative structures of living unfamiliar to the last three generations of Americans signal new forms of urbanization. 


\section{Notes}

1. Michel S. Laguerre, The Informal City (New York: St. Martin's Press, 1994), 42.

2. "State of Homelessness," National Alliance to End Homelessness, Washington DC, October 15, 2018, https://endhomelessness.org/homelessness-in-america/homelessnessstatistics/ state-of-homelessness-report/.

3. Andrew Heben, Tent City Urbanism: From Self-Organized Camps to Tiny Home Villages (Eugene OR, USA: The Village Collaborative, 2014), 12.

4. Ibid., 170.

5. Friedrich Engels, "Preface to the Second German Edition," The Housing Question, London, January 1887; or. ed. Friedrich Engels, "Zur Wohnungsfrage," published as a series of articles

in Volksstaat, Leipzig (Ger.), from June 26, 1872, till February 22, 1873: https://www.marxists.org/archive/marx/works/1872/housing-question/preface.htm. 6. Shelter-first solutions are countered by housing-first advocates who argue that the homeless are over managed in top-down formal shelter programs, inducing further dependence. Advocates call for immediate access to permanent housing without prerequisite qualifications and treatment followed by delivery of supportive services. Nonetheless, Northwest Arkansas is a fast-growing region with a $99 \%$ housing occupancy rate and significant shortages of affordable housing. Permanent housing to accommodate homeless populations is not available. For housing-first arguments see: Deborah K. Padgett, Benjamin F. Henwood, and Sam J. Tsemberis, Housing First: Ending Homelessness, Transforming Systems, and Changing Lives (New York: Oxford University Press, 2016).

7. Saskia Sassen, "The Informal Economy: Between New Developments and Old Regulations," Yale Law Journal 103, no. 8 (1994): 2304, http://digitalcommons.law.yale.edu/ ylj/vol103/iss8/8.

8. Brian Sloat, personal communication with the Author, 2018.

9. Kevin Fitzpatrick, email to the Author, February 25, 2019.

10. Padget et al., Housing First, viii, 7.

11. Kevin Fitzpatrick, email to the Author, February 22, 2019.

12. Sassen, "The Informal Economy," 2302. Sassen states: "Upgrading is likely to demand greater flexibility in the implementation of existing codes and acknowledgement by city officials that compliance may require several phases...Beyond mildly accommodating policies, one

might even envision a more drastic redrawing of regulatory frameworks, on the theory that current developments have rendered the old frameworks obsolete."

13. Hannah Wood, "Recycled Buildings: How to Design for Disassembly," Archinect, June 6, 2018, https://archinect.com/features/article/150067785/recycled-buildings-how-to-designfordisassembly.

14. Ciara Turner, "It Takes a Village: Designating 'Tiny House' Villages as Transitional Housing Campgrounds," University of Michigan Journal of Law Reform 50, no. 4 (2017): 931, http://repository.law.umich.edu/mjlr/vol50/iss4/4.

15. Ibid., 947-52.

16. See our manual for recommended landscape-based stormwater management strategies in lieu of hard engineering involving pipes and ponds. University of Arkansas Community Design Center, Low Impact Development: A Design Manual for Urban Areas (Fayetteville AR, USA: University of Arkansas Community Design Center, 2010).

17. Zeo Loftus-Farren, "Tent Cities: An Interim Solution to Homelessness and Affordable Housing Shortages in the United States," California Law Review 99, no. 4 (2011): 1070, doi:10.15779/Z38HH6C.

18. Ibid., 1067.

19. Turner, "It Takes a Village," 935.

20. Ibid., 936.

21. For the distinction between mode versus sector in the informal see: Ananya Roy, "Urban Informality: Toward an Epistemology of Planning," Journal of the American Planning Association 71, no. 2 (Spring 2005): 148-50. 
22. Ariel Aberg-Riger, "When America's Basic Housing Unit Was a Bed, Not a House,"

CityLab, February 22, 2018, https://www.citylab.com/equity/2018/02/the-rise-and-fall-of-theamerican-sro/553946/.

23. Heben, "Tent City Urbanism," viii.

24. Valeria Frederighi, The Informal Stance: Representations of Architectural Design and Informal Settlements (San Francisco: Applied Research and Design Publishing, 2018), 132. 25. Ibid., 135.

26. Roy, "Urban Informality," 155.

27. Ibid., 156.

\section{Acknowledgment}

New Beginnings Transitional Homeless Village was designed by the University of Arkansas Community Design Center, an outreach center of the Fay Jones School of Architecture and Design, University of Arkansas.

Project Team: Stephen Luoni, Charles Sharpless, Ethan Kaplan, Garrett Grelle, and Shawna Hammon.

Consultants: WER Architects, Tatum Smith Engineers, The Marshall Group, Morrison Shipley Engineers, Omni Engineers, and Leslie Tabor Landscape Architect.

Project design fees to the University of Arkansas Community Design Center were provided by the client, Serve Northwest Arkansas.

Research funding was provided by the National Resilience Initiative of the Architects

Foundation and the American Institute of Architects.

Publication funding was provided by the University of Arkansas at Fayetteville and the UA Community Design Center.

Many thanks to Mayor Lioneld Jordan, Fire Marshal Brain Sloat, and the City of Fayetteville AR Planning Department for their efforts and collaboration in finding agreeable permitting solutions that will allow implementation of New Beginnings. We hope that other cities will find example in their leadership.

\section{Credits}

Figure 1: photo retrieved from The Orange County Register.

Figures 2-14: images by @ University of Arkansas Community Design Center.

Stephen Luoni is the Director of the University of Arkansas Community Design Center (UACDC) where he is the Steven L. Anderson Chair in Architecture and Urban Studies and a Distinguished Professor of Architecture. Under his direction since 2003, UACDC's design and research have won more than 150 awards, all for urban design, research, and education. Luoni's work specializes in interdisciplinary public interest projects, combining ecological engineering and landscape, urban, and architectural design.

E-mail: sluoni@uark.edu 